\title{
Pengembangan Media Pembelajaran Sistem Saraf Dengan Menggunakan Adobe Flash CS3 pada Siswa Kelas XI Sekolah Menengah Atas
}

\author{
Dian Arisetya ${ }^{1}$, Elly Djulia ${ }^{2}$, Hasruddin $^{3}$ \\ ${ }^{1}$ Dosen STKIP RIAMA Jl. Tritura No. 6, Harjosari II Medan Amplas, Kota Medan, Sumatera Utara 20147 \\ ${ }^{2}$ Program Studi Pendidikan Biologi Pascasarjana, Universitas Negeri Medan. Sumatera Utara. Indonesia \\ Email: Dianari35@yahoo.com
}

\begin{abstract}
This study was intended to: (1) identify the development of learning media procedure nervous system with Adobe Flash CS3 for XI grade high school student; (2) figure up the student's responds to learning media development of nervous system with Adobe Flash CS3 for XI grade high school student. This study was classified as Borg \& Gall model development that included to 6 steps (1) Information collection; (2) Designing; (3) pre-product development; (4) expert validation; (5) revision; (6) post product testing. The subject of this research was XI grade high school student of SMA N 1 Rantau Selatan LabuhanBatu at 2012/2013 academic year. This study was designed by questionnaire method (Linkert scale) that administered for testing to two media experts, two matter experts, three personals, 9 small groups, and 30 bounded field. The collected data was analyzed by applying descriptive analysis, qualitative analysis and inferential analysis by employing SPSS version software 19.0 for Windows. The analysis revealed the test by (1) learning media experts (89\%); (2) learning biology matter expert (83\%); (3) personal (83\%); (4) small groups (91\%); (5) bounded field $(94 \%)$. The scores indicate that responses from media experts, matter experts and student to biology learning media development with Adobe Flash CS 3 for nervous system for high school student is very good categorized.
\end{abstract}

Key words: Borg \& gall learning development model, adobe flash CS3, learning media, nervous system.

\section{PENDAHULUAN}

Kemajuan ilmu pengetahuan dan teknologi telah berpengaruh terhadap penggunaan alat-alat bantu mengajar di sekolah-sekolah dan lembaga-lembaga pendidikan lainnya. Bagi sekolah-sekolah yang sudah maju dan mampu, telah menggunakan alat-alat tersebut sebagai alat bantu mengajar, sehingga pembelajaran menjadi lebih efektif dan efisien. Namun yang perlu diperhatikan adalah semua peralatan dan perlengkapan sekolah tersebut harus disesuaikan dengan tuntutan kurikulum dengan materi, metode, dan tingkat kemampuan siswa untuk mencapai tujuan pembelajaran. Maka para pengajar diharapkan dapat menggunakan alat-alat atau perlengkapan tersebut secara efektif dan efisien dalam pembelajaran di kelas. Alat bantu yang dipakai adalah alat bantu visual, misalnya gambar, model, objek, dan alat-alat lain yang dapat memberikan pengalaman konkrit, motivasi belajar, mempertinggi daya serap, dan hasil belajar siswa. Selain memusatkan perhatian pada alat bantu visual yang dipakainya orang kurang memperhatikan aspek desain, pengembangan pembelajaran (instruction), produksi, dan evaluasinya.

Teknologi informasi lebih baik dibanding dengan pembelajaran tradisional atau konvensional. Menurut O'day (2006) animasi merupakan alat visualisasi yang efektif dibandingkan gambar statis pada pelajaran biologi sel. Penelitian selanjutnya O'Day (2008) menyatakan siswa yang melihat animasi memperoleh skor tes secara signifikan lebih tinggi daripada siswa yang tidak melihat animasi, dan daya ingat siswa dapat meningkat $87-93 \%$ dari informasi yang diperoleh dengan melihat animasi menggunakan narasi. Salah satu faktor yang berpengaruh dalam peningkatan mutu pendidikan adalah media pembelajaran yang digunakan dalam proses pembelajaran di kelas, yang mendukung salah satu indikator pendidikan yang berkualitas dan sangat berperan dalam mempersiapkan anak didik untuk memperoleh hasil belajar yang berprestasi di sekolah.

Rendahnya hasil belajar siswa dapat disebabkan oleh tidak tepatnya media 
pembelajaran dan tidak digunakannya media pembelajaran yang ada semaksimal mungkin. Guru di Sekolah Menengah Atas Negeri 1 Rantau Selatan menyatakan bahwa hasil nilai ujian harian siswa pada materi sistem saraf masih dibawah Kriteria Ketuntasan Minimal (KKM) yang mencapai 70, hal ini dilihat dari hasil nilai rata-rata ulangan harian siswa kelas XI pada materi sistem saraf selama kurun waktu dua tahun terakhir yaitu: (1) Tahun pembelajaran 2010/2011, rata-rata nilai siswa 65; (2) Tahun pembelajaran 2011/2012, rata-rata nilai siswa 67 (Guru Biologi Sekolah Menengah Atas Negeri 1 Rantau Selatan). Sumber daya yang dibutuhkanpun sangat beragam sesuai materi dan kondisi pembelajaran yang akan dilaksanakan. Guru dituntut mampu menganalisis kebutuhan, merancang, mendesain, menemukan, memproduksi, dan menggunakan berbagai jenis sumber belajar sesuai dengan Permendiknas No.16 Tahun 2007 dengan menggunakan media pembelajaran Biologi berbasis teknologi informasi. Pembelajaran yang efektif akan terjadi jika bahan media pembelajaran Biologi yang diperlukan tersedia. Salah satu komponen yang perlu dipersiapkan adalah sumber belajar salah satunya media pembelajaranBiologi yang menggunakan adobe flash CS3 yang memodifikasi gambar-gambar animasi, suara dan video.Sistem saraf merupakan salah satu materi pelajaran biologi yang mengandung konsep-konsep abstrak, yang sulit untuk dipahami oleh siswa. Penyajian sistem saraf menuntut kemampuan guru untuk mengorganisasi isi pelajaran sebagai persiapan untuk membangun pengetahuan siswa. Dalam hal ini guru dapat merancang materi sistem saraf dengan menggunakan adobe flash CS3 agar konsep sistem saraf yang bersifat abstrak dapat disajikan secara konkret.

Dari hasil observasi yang dilakukan, peneliti mencoba menggunakan media pembelajaranBiologi dengan menggunakan adobe flash CS3 dalam mengembangkan materi sistem saraf pada kelas XI Sekolah Menengah Atas.
Diharapkan nantinya akan menghasilkan proses belajar biologi yang efektif dan efisien serta dapat meningkatkan hasil belajar siswa yang lebih baik dari sebelumnya. Guru dapat lebih mudah menjelaskan materi biologi khususnya sistem saraf dan siswa dapat lebih mudah memahaminya sehingga akan mengakibatkan termotivasinya siswa untuk lebih aktif lagi dalam belajar sistem saraf.

Berdasarkan hasil penelitian Fitria (2010) menyatakan Program Aplikasi Multimedia Mata Pelajaran Biologi Tentang Pembelajaran Sistem Pencernaan Manusia Bagi Siswa Kelas VII dengan menggunakan software adobe flash CS3 dapat menggabungkan gambar, suara dan animasi gerak sehingga membantu siswa untuk memahami dan mengetahui materi sistem pencernaan dan membantu siswa dalam menghafal nama-nama organ pencernaan yang ada didalam tubuh manusia. Media pembelajaran adalah sebuah alat yang berfungsi dan digunakan untuk menyampaikan pesan pembelajaran. Menurut Edgar Dale (dalam Rusman, 2011), dalam penggolongan pengalaman belajar yang dituangkan dalam cone experience atau kerucut pengalaman, mengemukakan bahwa belajar yang paling baik adalah belajar dari pengalaman langsung.

Menurut Gerlach dan Ely (dalam Rusman, 2011), ada tiga ciri media yang merupakan petunjuk mengapa media digunakan dan apa saja yang dapat dilakukan oleh media yang mungkin guru tidak mampu melakukannya, yaitu: (1) ciri fiksatif: yang menggambarkan media merekam, menyimpan, melestarikan, dan merekomdasikan, merekonstruksi suatu peristiwa atau objek, (2) ciri manipulatif: transformasi suatu kejadian atau objek yang memakan waktu lama dapat disajikan kepada siswa dalam waktu sekejap dengan teknik pengambilan gambar time-lapse recording, dan (3) ciri distributif: ciri ini memungkinkan suatu objek atau kejadian ditransportasikan melalui ruang dan secara bersamaan kejadian tersebut disajikan kepada sejumlah besar siswa dengan 
stimulus pengalaman yang relatif sama mengenai kejadian itu.

Menurut Sharon et.al (2011) dalam bukunya "Instructional Technology and Media for Learning”, belajar adalah mengembangkan pengetahuan baru, keterampilan, dan perilaku yang merupakan interaksi individu dengan informasi dan lingkungan. Menurut Yamin (dalam Musfiqon, 2012), mengatakan faktor-faktor yang mempengaruhi belajar diantaranya: (1) bakat dan kecepatan belajar, (2) kemampuan untuk menguasai pelajaran, (3) mutu program pembelajaran, (4) ketahanan (perseverance), dan (5) waktu. Adobe flash CS3 adalah software grafis animasi yang dapat membuat objek grafis dan menganimasikannya sehingga kita dapat langsung membuat objek desain tanpa harus menggunakan software grafis pendukung seperti illustrator atau photoshop. Adobe flash memiliki kemampuan untuk membuat animasi mulai dari yang sederhana hingga kompleks. Adobe flash dapat menggabungkan gambar, suara, dan video ke dalam animasi yang dibuat. Berkas yang dihasilkan dari perangkat lunak ini mempunyai file extension fla. File ini kemudian dapat dipublikasikan sehingga dihasilkan file .swf.

\section{METODE PENELITIAN}

Penelitian dilakukan di Sekolah Menengah Atas Negeri 1 Rantau Selatan Labuhanbatu pada siswa kelas XI. Prosedur pengembangan yang dilakukan dalam penelitian pengembangan media pembelajaran dengan menggunakan adobe flash CS3 pada materi sistem saraf untuk kelas IX Sekolah Menengah Atas hanya dilakukan 6 tahap sesuai dengan jenis penelitian yang dikembangkan oleh Borg \& Gall yaitu: (1) Tahap I: Analisis kebutuhan, bertujuan untuk mengumpulkan informasi yang relevan dengan perlunya pengembangan media pembelajaran sistem saraf dengan menggunakan adobe flash CS3. Perumusan tujuan dan butir-butir materi bertujuan untuk mengembangkan desain pembelajaran sesuai dengan silabus Kurikulum Tingkat Satuan Pendidikandan Rencana Pelaksanaan Pembelajaran sebagai bahan untuk mengembangkan media pembelajaran sistem saraf dan melakukan observasi jumlah siswa, (2) Tahap II: Desain media, bertujuan untuk merencanakan materi pembelajaran sesuai dengan silabus Kurikulum Tingkat Satuan Pendidikan dan untuk menghasilkan produk awal sebelum diteskan kepada siswa dan pembuatan naskah dan perekaman suara untuk media pembelajaran sistem saraf, (3) Tahap III: Pembuatan media dan memproduksi media pembelajaran ke dalam bentuk CD-ROM pembelajaran yang berisikan deskripsi singkat, standar kompetensi dan kompetensi dasar, quis interaktif, uraian materi, kesimpulan dan soal latihan pemahaman, (4) Tahap IV: Validasi desain ahli materi dan media yang divalidkan oleh dua dosen ahli, (5) Tahap V: Uji coba produk media, dilakukan untuk mengetahui daya tarik siswa terhadap produksi media pembelajaran sistem saraf dengan adobe flash CS3, yang dilakukan pada uji coba kelompok perorangan (3 orang), uji coba kelompok kecil (9 orang), uji coba lapangan (30 orang) terbatas dengan karakteristik siswa kemampuan rendah, sedang dan tinggi serta pengumpulan data dengan menggunakan angket (skala linkert), (6) Tahap VI: Hasil akhir, merupakan produk media pembelajaran sistem saraf yang telah valid dan direvisi sesuai dengan masukan serta saran-saran, sehingga terbentuklah media pembelajaran Biologi berupa CD pembelajaran sistem saraf dengan menggunakan adobe flash CS3.

Revisi pertama berupa masukan serta saran-saran dari hasil dua validasi ahlimateri fisiologi hewan ibu Dra. Melva Silitonga, MS dan bapak Prof. Dr. Herbert Sipahutar, M.Sc. dan dua dosen ahli media bapak Dr. Rachmat Mulyana,M.Si., dan Prof. Dr. Muhammad Badiran, M.Pd., Tahapan ini bertujuan untuk mengetahui kelayakan produk yang dikembangkan dalam media pembelajaran biologi sistem saraf dengan menggunakan adobe flash CS3 pada siswa kelas XI Sekolah Menengah Atas. Revisi kedua terhadap produk dari hasil uji coba perorangan terdiri dari 3 orang siswa apabila membutuhkan 
revisi. Uji coba kelompok kecil yang dilakukan terhadap 9 orang siswa apabila membutuhkan revisi. Uji coba kelompok lapangan terbatas yang dilakukan terhadap 30 orang siswa yaitu di kelas XI-3 Sekolah Menengah Atas Negeri 1 Rantau Selatan, dengan karakteristik siswa kemampuan rendah, sedang dan tinggi. Pengumpulan data dengan menggunakan angket (skala linkert). Revisi keempat terhadap produk dari hasil uji coba kelompok lapangan terbatas apabila membutuhkan revisi.

Pengambilan data pada penelitian ini, melalui: (1) aspek kesederhanaan program desain, berupa kejelasan materi dan kesesuaian isi dengan rencana pelaksanaan pembelajarandan indikator pembelajaran untuk mencapai tujuan pembelajaran yang diperoleh dari ahli materi pembelajaran: (2) keterpaduan, berupa kejelasan gambar dan tulisan serta kualitas program yang digunakan yang diperoleh dari uji coba perorangan, uji coba kelompok kecil, dan uji coba lapangan terbatas: (3) penekanan, kejelasan kualitas tampilan gambar dan penyajian materi, diperoleh dari uji coba perorangan, kelompok kecil dan lapangan terbatas: (4) keseimbangan, berupa kejelasan ukuran, tulisan dan kesesuaian halaman pada gambar agar terlihat menarik, diperoleh dari uji coba perorangan, uji kelompok kecil, dan uji lapangan terbatas: (5) bentuk gambar, berupa kejelasan dan kesesuaian warna gambar tiap halaman agar mudah dipahami, diperoleh dari uji coba perorangan, uji kelompok kecil, dan uji lapangan terbatas: dan (6) warna gambar, berupa warna gambar pada tulisan harus sesuai sehingga mudah dibaca, diperoleh dari uji coba perorangan, uji kelompok kecil, dan uji lapangan terbatas.

\section{HASIL DAN PEMBAHASAN}

Penilaian ahli materi pembelajaran terhadap media pembelajaran Biologi sistem saraf dengan menggunakan Adobe Flash CS3 yang dikembangkan termasuk kategori "sangat baik" yang pengaturan isi pembelajaran memperhatikan tujuan pembelajaran dari materi sistem saraf.
Tabel 1. Rata-rata Hasil Penilaian Terhadap Media Pembelajaran Biologi Oleh Ahli Media

\begin{tabular}{llll}
\hline No & Kategorisasi & $\begin{array}{l}\text { Penilaian } \\
\text { ahli media } \\
(\%)\end{array}$ & Kriteria \\
\hline 1 & Aspek Program & $92 \%$ & $\begin{array}{l}\text { Sangat } \\
\text { Baik }\end{array}$ \\
\hline 2 & $\begin{array}{l}\text { Aspek desain } \\
\text { pembelajaran }\end{array}$ & $91 \%$ & $\begin{array}{l}\text { Sangat } \\
\text { Baik }\end{array}$ \\
\hline 3 & $\begin{array}{l}\text { Aspek } \\
\text { komunikasi } \\
\text { visual }\end{array}$ & $92 \%$ & $\begin{array}{l}\text { Sangat } \\
\text { Baik }\end{array}$ \\
\hline & Rata-rata & $92 \%$ & $\begin{array}{l}\text { Sangat } \\
\text { Baik }\end{array}$ \\
\hline
\end{tabular}

Tabel 2. Rata-rata Hasil Penilaian Terhadap Media Pembelajaran Biologi Oleh Ahli Materi

\begin{tabular}{llll}
\hline No & Kategorisasi & $\begin{array}{l}\text { Penilaian } \\
\text { ahli materi } \\
(\%)\end{array}$ & Kriteria \\
\hline 1 & Kelayakan isi & $79 \%$ & Baik \\
\hline 2 & Penyajian & $84 \%$ & Sangat Baik \\
\hline 3 & Kebahasaan & $88 \%$ & Sangat Baik \\
\hline 4 & Kegrafikan & $80 \%$ & Sangat Baik \\
\hline Rata-rata & $83 \%$ & Sangat Baik \\
\hline
\end{tabular}

Hasil penilaian uji coba kelompok perorangan menyatakan media pembelajaran sistem saraf yang sudah dikembangkan dinyatakan ", sangat baik", dengan skor $83 \%$. Pada uji coba kelompok kecil meningkat menjadi kesederhanaan (91\%), keseimbangan (87\%), bentuk gambar (91\%) dan penekanan (87\%) dengan kriteria "sangat baik". Pada tahap uji coba kelompok kecil yang dinyatakan sangat baik, maka tidak perlu diadakan revisi sehingga dapat dilanjutkan pada uji coba lapangan terbatas. Selanjutnya, uji coba lapangan terbatas dilakukan kepada 30 siswa kelas XI-3 di Sekolah Menengah Atas Negeri 1 Rantau Selatan. Pada uji coba ini diperoleh hasil tanggapan siswa terhadap media pembelajaran sistem saraf yang telah dikembangkan mendapatkan kriteria "sangat baik", dengan persentase rata-rata $94 \%$. Penilaian uji coba lapangan terbatas ini menjadi tahap akhir dari uji coba produk.

Hasil penelitian menunjukkan bahwa rata-rata siswa yang dibelajarkan dengan menggunakan media pembelajaran biologi (eksperimen) lebih tinggi dibandingkan dengan siswa yang dibelajarkan tanpa 
menggunakan media pembelajaran biologi (kontrol). Hasil belajar siswa akan meningkat jika guru menggunakan media pembelajaran dalam proses belajar biologi di kelas, dengan media pembelajaran biologi materi sistem saraf yang bersifat abstrak dapat divisualisasikan menjadi konkret dan siswa akan menjadi lebih memahami dan mengerti akan materi sistem saraf yang diajarkan, sehingga hasil belajar yang diharapkan dapat tercapai sesuai dengan Standard Kriteria Ketuntasan Minimal (KKM).

Hal-hal yang menyebabkan media animasi lebih unggul adalah visualisasi yang disajikan melalui animasi memungkinkan pembelajar melakukan navigasi, berinterakasi, berkreasi dan berkomunikasi dengan menghubungkan panca indera mereka dengan antusias sehingga informasi yang masuk ke dalam memorinya lebih tahan lama dan mudah untuk diulang kembali saat informasi itu diperlukan lagi (O’Day, 2007).

Hasil dari penilaian ini menyimpulkan bahwa media pembelajaran sistem saraf dengan menggunakan adobe flash CS3 pada pembelajaran biologi yang dikembangkan mendapat tanggapan yang sangat baik bagi siswa sebagai pengguna produk. Berdasarkan analisis hasil penilaian pada uji coba lapangan terbatas yang dilakukan terhadap 30 orang siswa kelas XI-3 di Sekolah Menengah Atas Negeri 1 Rantau Selatan tidak terdapat saran perbaikan produk media sehingga produk dapat digunakan sebagai bahan ajar pada pelajaran Biologi sistem saraf.

\section{SIMPULAN}

Berdasarkan hasil dan pembahasan penelitian maka dapat disimpulkan dari hasil validasi dari ahli media (89\%), ahli materi (83\%), dan tanggapan uji coba perorangan $(87 \%)$, uji coba kelompok kecil (91\%), dan uji coba kelompok terbatas
(94\%) mengenai pengembangan media pembelajaran sistem saraf dengan adobe flash CS3 secara keseluruhan termasuk dalam kategori 'sangat baik'. Karena membantu siswa dalam memahami materi sistem saraf yang diajarkan, dengan cara konsep-konsep yang bersifat abstrak dengan menggunakan adobe flash CS3 dapat divisualisasikan menjadi lebih konkret.

\section{DAFTAR PUSTAKA}

Arikunto, S. (2012). Dasar-Dasar Evaluasi Pendidikan. Edisi 2. Jakarta : Bumi Aksara.

Fitria, D. (2010). Aplikasi Multimedia Mata Pelajaran Biologi tentang Pembelajaran Sistem Pencernaan Manusia bagi Siswa Kelas VII. Skripsi. Program Studi Teknik Informatika Fakultas Ilmu Komputer. Universitas Mercu Buana.

Musfiqon. (2012). Pengembangan Media dan Sumber Pembelajaran. Jakarta : PT. Prestasi Pustakaraya.

O’Day, D. H. (2006). Animated Cell Biology: A Quick and Easy Method for Making Effective, High-Quality Teaching Animations. CBE-Life Sciences Education. 5(4): 255-263.

O'Day, D. H. ( 2007). The Value Of Animations in Biology Teaching: A Study of Long-Term Memory Retention. CBE-Life Sciences Education, 6(2):217-223.

Permendiknas (2007). Tentang Standar Kualifikasi Akademik dan Kompetensi Guru. Jakarta : Menteri Pendidikan Nasional, P.P. No. 16.

Rusman, K. D. dan Riyana C. (2011). Pembelajaran Berbasis Teknologi Informasi dan Komunikasi. Bandung : Rajawali Press.

Sanjaya, W. (2012). Media Komunikasi Pembelajaran. Jakarta: Kencana Prenada Media Group.

Sharon, E. S. (2011). Instructional Technology \& Media for Learning. Jakarta : Kencana.

Script. 1. (2008). Panduan Mudah Membuat Animasi. Jakarta : Mediakita. 